\title{
LARYNX TUMOR TISSUE RESPONSE TO PHOTODYNAMIC THERAPY WITH ROSE BENGAL
}

\author{
ŁUKASZ OŻÓG ${ }^{1}$, WOJCIECH DOMKA² DOROTA BARTUSIK-AEBISHER ${ }^{3}$ \\ and DAVID AÉBISHER ${ }^{1 *}$
}

\author{
'Department of Photomedicine and Physical Chemistry, \\ Medical College of The University of Rzeszow, Rzeszow, Poland \\ ${ }^{2}$ Department of Otolaryngology, Medical College of The University of Rzeszow, \\ Rzeszow, Poland \\ ${ }^{3}$ Department of Biochemistry and General Chemistry, \\ Medical College of The University of Rzeszow, Rzeszow, Poland
}

\begin{abstract}
Larynx tissue with cancers or early recurrences of cancer tend to have a positive response to Photodynamic Therapy (PDT). The goal of this study was to achieve tumor cell killing such as larynx and tongue with the use of photosensitizer, oxygen and laser light. The presented study indicated that PDT is an effective primary or alternative treatment modality for carcinomas in larynx tissue.
\end{abstract}

Keywords: Rose Bengal, singlet oxygen, photodynamic therapy, larynx tissue

Photodynamic therapy (PDT) is a well-known method of fighting cancer today. PDT is a cancer treatment that uses photo-generated reactive oxygen species to damage targeted cancer cells. The method uses a photosensitizing agent (photosensitizer - PS), which selectively localizes in tumors, and then after tumor-induced activation causes tumor necrosis. PDT is a method based on the photochemical reaction between said PS, light of appropriate wavelength, and molecular oxygen. When these three harmless single ingredients are present together, reactive oxygen species (ROS) are generated (1). The resulting ROS are able to damage cells, the vascular system, or induce inflammatory and immune responses. The PDT procedure consists of two stages: in the first stage, PS is administered intravenously, intraperitoneally or locally; in the second stage, the place where the PS has accumulated and which is to be damaged is exposed to light (2). However, we are currently conducting research on improving PDT and attempting to apply this method of treatment in ever more cases. For the generation of reactive oxygen species, a photodynamic treatment method employs photosensitizers that are excited by external illumination provided by visible light at power levels that do not damage healthy tissue.

The first attempts to use PDT for head and neck cancers date back to the 1980s (3-6). In 1984, Wile et al. conducted a pilot study in which they used a hematoporphyrin (HpD) derivative as a photosensitizing agent for the treatment of head and neck cancer. 21 patients took part in this study. The treated areas were illuminated with light at $640 \mathrm{~nm}$. The test results were positive, but the technique required further research (4). In 1985, Carruth and McKenzie from the UK published a report from a PDT study for the treatment of head and neck cancers. The results indicated that the tumors responded to PDT treatment, and in a few cases complete tumor regression was achieved (5). Attempts to use PDT for early squamous cell carcinoma of the upper respiratory tract were also brought to the University of Cincinnati. The results of these tests confirmed that PDT can be used as an alternative form of treatment for this type of cancer (6). Yoshida et al. Also reported positive attempts to use PDT for larynx cancer. in 1995 (7). Research on this form of treatment in the case of head and neck cancers has seen quite a lot in recent years $(8,9)$. However, new

\footnotetext{
* Corresponding author: e-mail: daebisher@ur.edu.pl
} 
works are constantly being developed that describe the use of PDT in the case of neck cancer (10-12).

In addition to research into the very possibility of using PDT in neck cancers, it is important to develop a method to monitor the effects of PDT. As we mentioned earlier, molecular oxygen is required to initiate photodynamic action, which is consumed during lighting. It is this relationship, consisting of changing the concentration of oxygen in the tissue structure, allows the use of magnetic resonance imaging (MRI) to assess the operation of PDT. In our research, we used the T2 mapping sequence to evaluate the change in oxygen concentration in tissue. This is the MRI technique that acquires multiple echoes at different TE times at each slice location that represents different $\mathrm{T} 2$ weighting. The acquired data can be processed to produce $T_{2}$ color maps which demonstrate more subtle changes in tissue structure that are not visible on grayscale MR images. $\mathrm{T}_{2}$ relaxation mapping with MRI can help visualize and quantitatively evaluate the oxygen content of tissue, which can be important as an assessment of the effectiveness of photodynamic therapy. The changes in $T_{2}$ values correlate with the variations in water and oxygen content (13). $\mathrm{T}_{2}$ is a tissue-specific time parameter that differs between tissues. There is no precise value for the specific tissue but is constant for given magnetic field strength. Abnormal tissues, on the other hand, tend to have a higher $\mathrm{T}_{2}$-value than normal tissue. The value of $\mathrm{T}_{2}$ depends on the tissue type, the structure of the environment, and the mobility of protons (14-16).

Expected changes in $\mathrm{T}_{2}$ relaxation time after individual stages of the experiment:

a) water due to the longer $T_{2}$ relaxation time than the tissue should cause an increase (significant / large increase $\uparrow \uparrow$ ) in the average $T_{2}$ time of tissue;

b) Rose Bengal should not affect the change in time $\mathrm{T}_{2}$, as confirmed by our previous experiments;

c) oxygen ${ }^{3} \mathrm{O}_{2}$ contained in tissues and water, according to literature knowledge and our previous research results, reduces the average $T_{2}$ relaxation time $(\uparrow)$ of the examined tissue;

d) according to our previous research results and information available in the literature on the effect of singlet oxygen ${ }^{1} \mathrm{O}_{2}$ on relaxation times in MRI, as well as due to ${ }^{3} \mathrm{O}_{2}$ oxygen consumption, we expected a reduction in $\mathrm{T}_{2}$ time $(\uparrow)$ due to ${ }^{1} \mathrm{O}_{2}$ singlet oxygen generation;

e) irradiation of water alone, or irradiation of $\mathrm{RB}$ alone, or irradiation of $\mathrm{RB}+$ water does not change the relaxation time $\mathrm{T}_{2}$;

Based on the above points (a, b, c, d, e) we assumed that the average $T_{2}$ time measured in step I of the tissue itself should increase in step II due to the influence of water / RB / 3O2, which were introduced by injection into the tissue. In step III, we expected another increase in $\mathrm{T}_{2}$, caused solely by oxygen consumption because it was the only com-
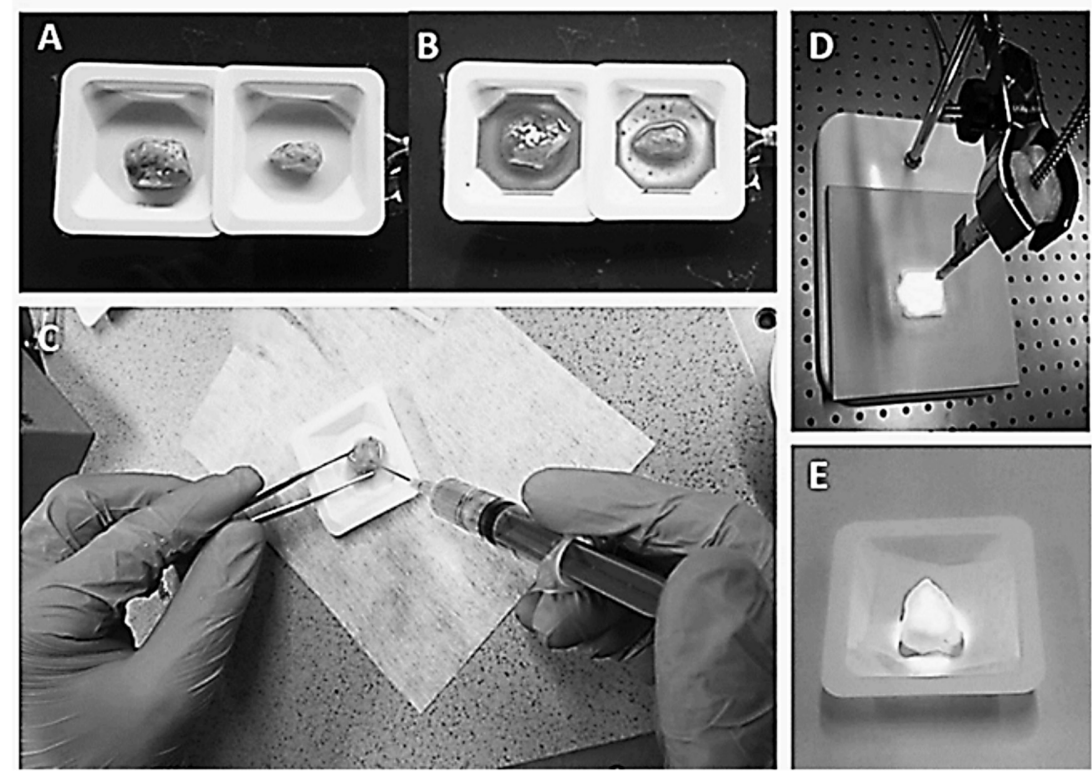

Figure 1. Cancer tissue and healthy tissue of larynx before and after injection of $\mathrm{H}_{2} \mathrm{O}+\mathrm{RB}+\mathrm{O}_{2}$ (A and B) and during injection (C). Setup of PDT part of the experiment (D) and larynx tissue during irradiation (E). 
Table 1. Expected changes in $\mathrm{T}_{2}$ relaxation time after individual stages of the experiment.

\begin{tabular}{|c|c|c|c|c|c|c|}
\hline I step & \multicolumn{2}{|c|}{ II step } & \multicolumn{2}{|c|}{ III step } & \multicolumn{2}{|c|}{ IV step } \\
\hline $\begin{array}{l}\text { MRI measurements } \\
\text { of tissue structure }\end{array}$ & \multicolumn{2}{|c|}{$\begin{array}{l}\text { MRI measurements of tissue } \\
\text { structure }+\mathrm{H}_{2} \mathrm{O}+\mathrm{RB}+{ }^{3} \mathrm{O}_{2}\end{array}$} & \multicolumn{2}{|c|}{$\begin{array}{l}\text { MRI measurements of tissue } \\
\text { ructure }+\mathrm{H}_{2} \mathrm{O}+\mathrm{RB}+{ }^{3} \mathrm{O}_{2}+\mathrm{hv}\end{array}$} & \multicolumn{2}{|c|}{$\begin{array}{l}\text { MRI measurements of tissue } \\
\text { structure }+\mathrm{H}_{2} \mathrm{O}+\mathrm{RB}+{ }^{3} \mathrm{O}_{2}+\mathrm{hv}\end{array}$} \\
\hline \multirow{3}{*}{ - } & $\mathrm{H}_{2} \mathrm{O}$ & $\mathrm{T}_{2}: \uparrow \uparrow$ & $\mathrm{hv}+\mathrm{H}_{2} \mathrm{O}$ & No changes $T_{2}$ & $\mathrm{hv}+\mathrm{H}_{2} \mathrm{O}$ & no changes $T_{2}$ \\
\hline & $\mathrm{RB}$ & No changes $T_{2}$ & \multirow{2}{*}{$\begin{array}{c}\mathrm{h} v+\mathrm{RB}+ \\
{ }^{3} \mathrm{O}_{2} \rightarrow \mathrm{O}_{2}\end{array}$} & \multirow{2}{*}{$\mathrm{T}_{2}: \uparrow$} & $h v+R B+$ & \multirow{2}{*}{$\mathrm{T}_{2}: \uparrow$} \\
\hline & ${ }^{3} \mathrm{O}_{2}$ & $\mathrm{~T}_{2}: \downarrow$ & & & $3 \mathrm{O}_{2} \rightarrow \mathrm{O}_{2}$ & \\
\hline $\mathrm{T}_{2}-$ const. & \multicolumn{2}{|c|}{$\mathrm{T}_{2}-\uparrow$} & \multicolumn{2}{|c|}{$\mathrm{T}_{2}-\uparrow$} & \multicolumn{2}{|c|}{$\mathrm{T}_{2}-\uparrow$} \\
\hline
\end{tabular}

ponent that changed under the influence of light (water and RB did not change their time $\mathrm{T}_{2}$ under the influence of light). In step III, we also expected an increase in $\mathrm{T}_{2}$ time under the influence of light, but we expected a smaller or very small increase in $\mathrm{T}_{2}$ time because it was dependent on how much oxygen that could reduce consumption was left after previous exposure.

\section{EXPERIMENTAL}

\section{Chemicals}

Rose Bengal (RB) disodium salt (95\%), Oxygen (99\%) gas were purchased from STP\&DIN Chemicals, Bielsko-Biała, Poland. Water was purified with an AquaB Duo reverse osmosis water treatment system, Fresenius Medical Care, Singapore Pte. Ltd prior to use.

\section{Excised tissue}

Freshly excised samples of normal and cancerous laryngeal tissue and normal and cancerous thyroid tissue were obtained from the Frederic Chopin Clinical Regional Hospital No. 1 in Rzeszów, Poland. The human tissue studies were approved by the Bioethical Commission of the District Medical Chamber in Rzeszów (Resolution number 105/B/2017). Once received, the tissues were stored in $15 \mathrm{~mL}$ polypropylene graduated conical test tubes fitted with a screw tight cap (Kartell Labware, Milano, Italy) at $5^{\circ} \mathrm{C}$. The average size of the excised tissues was $10 \mathrm{~mm} \times 4 \mathrm{~mm} \times 5 \mathrm{~mm}$, respectively.

\section{Temperature, pH, and dissolved oxygen measure- ments}

Temperature, $\mathrm{pH}$, and concentration of dissolved oxygen (in ppm) were measured with an Elmetron multimode CPR-411 probe (Elmetron, Zabrze, Poland).

\section{Microscopic analysis}

After PDT, tissue samples were subjected to histological evaluation. Histological examination was performed using a Leica DM1000 LED microscope (LEICA Microsystems, Wetzlar, Germany) equipped with a binocular viewing head with $10 \mathrm{x}$; $20 \mathrm{x} ; 40 \mathrm{x}$ and $63 \mathrm{x}$ magnification. The microscope was additionally equipped with a Leica DMC2900 digital camera with LAS (Leica Application Suite, Version 4.8.0) software.

\section{Experimental setup}

A volume of Rose Bengal $\left(1.55 \times 10^{-5} \mathrm{~mol}\right)$ solution saturated with oxygen was injected into the larynx tissues. Appropriate controls of photosensitizer without light or light without photosensitizer produced no response. Immediately after the injection of RB, the laryngeal tissues were taken to the MR imaging plant to determine the $\mathrm{T}_{2}$ time and perform the PDT. For PDT, a solid-state laser (LD Pumped All-Solid-State Green Laser, MGL-III-532 $\mathrm{nm} / 300 \mathrm{~mW}$ ) delivered $532 \mathrm{~nm}$ light, close to the maximum absorption of RB. The laser was coupled to a fiber optic cable. The treatment light covered the entire tumor and was distributed uniformly throughout the tissue. In addition, the distance of the light source from the tissue surface was selected so as not to cause excessive heating or drying of the tissue. The temperature on the surface of the tissue after 15 min of exposure did not exceed $30^{\circ} \mathrm{C}$. A total of 6 larynx cancer tissues and 5 normal larynx tissue were treated and imaged in this study.

\section{Magnetic Resonance Imaging and $\mathbf{T}_{2}$ Mapping}

Immediately after surgery to remove the tumor and after $\mathrm{H}_{2} \mathrm{O}+\mathrm{RB}+\mathrm{O}_{2}$ injection, high-resolution MR images were acquired from each tissue to determine $T_{2}$ relaxation times and $T_{2}$ maps because our research focuses on quick detecting of tissue oxygen consumption response during PDT. The tissues MR images were acquired using a 1.5 Tesla field MR scanner (Optima MR360 Advance, General Electric Healthcare, USA). A 3-inch surface coil was used for image acquisitions. Images with varying echo times (TEs) were then obtained using a commercial 
$\mathrm{T}_{2}$ MAPS sequence to enable $\mathrm{T}_{2}$ calculation. MR images were obtained at eight different echo-times $(9.2,18.4,27.6,36.9,46.0,55.2,64.4$ and 73.6 milliseconds) in one single acquisition $(\mathrm{TR}=650 \mathrm{mil}-$ liseconds, field of view $5.00 \mathrm{~cm} \times 5.00 \mathrm{~cm}$, matrix size $224 \times 224$, slice thickness $2.0 \mathrm{~mm}$, receiver bandwidth $31.25 \mathrm{kHz}, \mathrm{NEX}=3$ ). Typically, 1 coronal slice was acquired to cover all tissue through the middle. The total scan time to simultaneously acquire the eight $\mathrm{T}_{2}$-weighted images was 7 min 20 sec. These MR parameters were used for all tissues.

\section{Statistical analysis}

The data were analyzed using Statistica 13.1 software (StatSoft Polska Sp.z o.o., Krakow, Poland). The data were analyzed using the dependent samples $t$-test to check the differences in the $\mathrm{T}_{2}$ time results between the individual steps of the experiment. Values were considered significantly different when the $p$-value was less than 0.05 .

\section{RESULTS AND DISCUSSION}

We used the software package READY View on work station AV4.6 (General Electric Health- care) to compute the $T_{2}$ maps. Second, we manually chose a layer that cuts the center of the tissue on which the $T_{2}$ maps were generated. On the $T_{2^{-}}$ weighted MR images, the tissues appeared as a bright region. One author manually drew the boundary of the tissue on the image and then saved the object map of the tissue. The $\mathrm{T}_{2}$ value for each voxel was determined within the tissue region (and the average value for the area was calculated). We compared the mean $\mathrm{T}_{2}$ values for the cancer tissues and normal tissues of the larynx.

$\mathrm{T}_{2}$ maps obtained during measurements are presented below. $\mathrm{T}_{2}$ maps of cancer and normal larynx tissues before and after PDT steps. $T_{2}$ maps were generated by single exponential fitting from multi-echo $(0-90 \mathrm{~ms})$ pulse sequences with intervals of $8.2 \mathrm{~ms}$, a time repetition of $650 \mathrm{~ms}$, and a field of view of $5 \mathrm{~cm}$ over $224 \times 224$ matrices. The T2 weight images and T2 maps of cancer and normal tissue are presented in Figure 2.

Mean $\mathrm{T}_{2}$ time values with standard deviation for all cancerous and healthy tissues are presented in Table 2 .

Measured and then determined $\mathrm{T}_{2}$ values in START point of cancer tissues $($ mean $=102.11$

Table 2. Mean values of T2 time (ms) for cancer and normal tissues in subsequent steps (START; after $\mathrm{H}_{2} \mathrm{O}+$ $\mathrm{RB}+\mathrm{O}_{2}$ injection; after $15 \mathrm{~min}$ of exposure; after $30 \mathrm{~min}$ of exposure).

\begin{tabular}{|l|c|c|}
\hline \multirow{2}{*}{ STEPS } & CANCER TISSUES & NORMAL TISSUES \\
\cline { 2 - 3 } & $(\mathrm{ms})$ & $(\mathrm{ms})$ \\
\hline START (tissue only) & $102.11 \pm 7.01$ & $89.41 \pm 9.59$ \\
\hline $\mathrm{H}_{2} \mathrm{O}+\mathrm{RB}+\mathrm{O}_{2}$ & $107.22 \pm 7.17$ & $94.43 \pm 10.26$ \\
\hline After 15 min hv & $109.62 \pm 6.86$ & $99.84 \pm 12.98$ \\
\hline After 30 $\mathrm{min} \mathrm{hv}$ & $109.38 \pm 6.80$ & $101.17 \pm 13.47$ \\
\hline
\end{tabular}

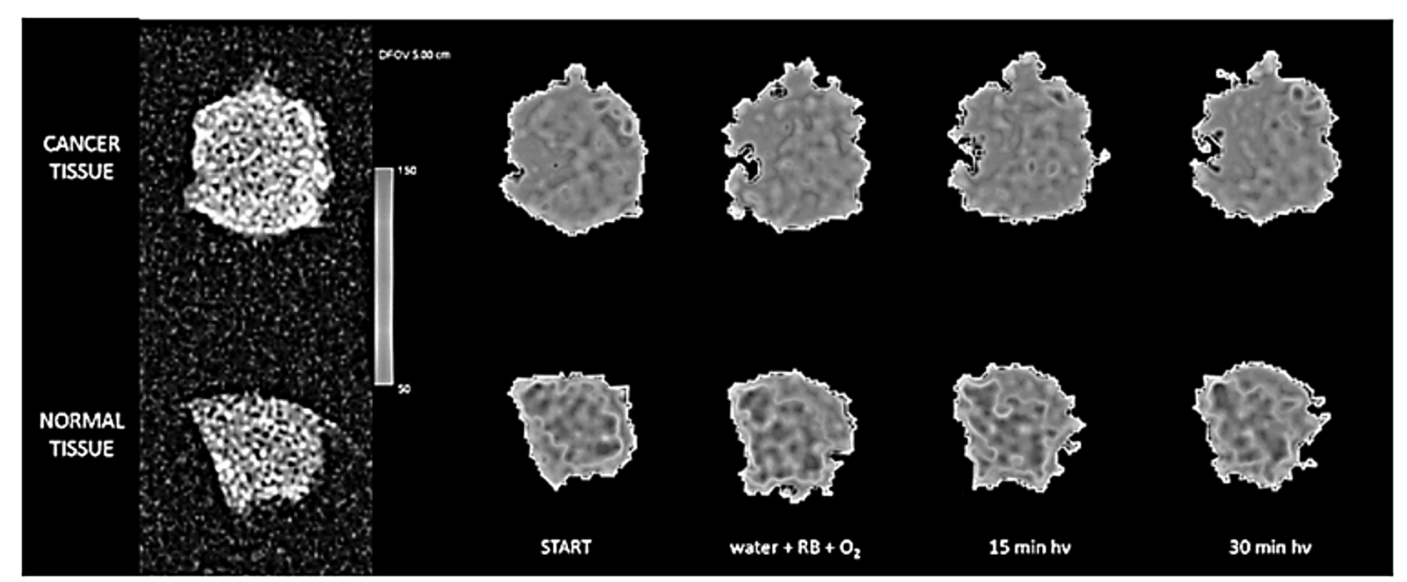

Figure 2. T2 weight images and $\mathrm{T}_{2}$ maps for cancer (top row) and normal (bottom row) larynx; warmer colors represent shorter $\mathrm{T}_{2}$ time. 
$\pm 7.01 \mathrm{~ms} ; \mathrm{n}=6)$ were significantly higher $(\mathrm{p}=$ $0.031 ; \mathrm{p}<0.05)$ than normal tissues (mean $=89.41$ $\pm 9.59 \mathrm{~ms} ; \mathrm{n}=5$ ), as shown in Figure 3 . The central rectangle shows the first quartile to the third quartile (interquartile range - IQR). A segment inside the rectangle (horizontal line) shows the median and "whiskers" above and below the box show the locations of the minimum and maximum measured $\mathrm{T}_{2}$ time. This result confirms that the $\mathrm{T}_{2}$ maps technique makes it possible to distinguish between healthy and cancerous tissue (Figure 3 ).

Addition of $\mathrm{H}_{2} \mathrm{O}+\mathrm{RB}+\mathrm{O}_{2}$ to both healthy and cancerous tissue did result in significant change $(\mathrm{p}<0.5)$ in $\mathrm{T}_{2}$ values $(\mathrm{p}=0.026$ for cancerous tissues; $\mathrm{p}=0.028$ for healthy tissues). The changes in $\mathrm{T}_{2}$ relaxation time in individual steps for cancer and normal tissues are shown in Figure 4 and Figure 5, respectively.

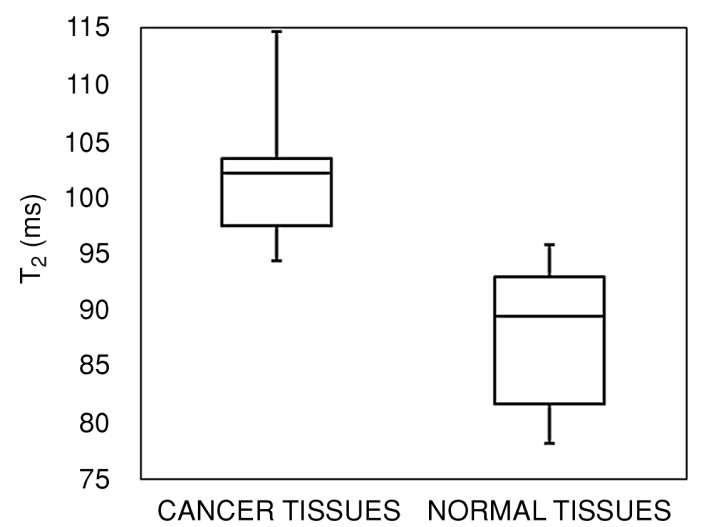

Figure 3. Box-Plot presents the medians, quartiles and extremes of $\mathrm{T}_{2}$ time for normal and cancer larynx tissues at the beginning of the experiment (START).
$\mathrm{T}_{2}$ values of tumors exposed of $15 \mathrm{~min}$ by laser light $($ mean $=107.22 \pm 7.17 \mathrm{~ms})$ did shows a significant change $($ mean $=p=0.000121 ; \mathrm{p}<0.05)$ compared to $\mathrm{T}_{2}$ values in previous step (after injection $\left.\mathrm{H}_{2} \mathrm{O}+\mathrm{RB}+\mathrm{O}_{2}\right)($ mean $=109.62 \pm 6.86 \mathrm{~ms})$. No significant change was observed between $15 \mathrm{~min}$ and $30 \mathrm{~min}$ of irradiation for cancer tissues $(\mathrm{p}=0.539$; $\mathrm{p}<0.05$ ). Exposure for 15 min consumed almost all of the oxygen inside the tissue. This result indicates that exposure for more than 15 min does not bring much change. For healthy tissues, a significant difference was observed between $15 \mathrm{~min}$ and $30 \mathrm{~min}$ irradiation ( $\mathrm{p}=0.037 ; \mathrm{p}<0.05)$.

The results from Tables 3 and 4 are graphically presented in Figures 4 and 5, respectively.

Histological examination of tumor tissues showed damage to the testicular cells of cancer cells due to PDT. Histological images showed visible epithelium of cancer with a picture of cellular pycnosis. In the case of healthy larynx tissues, histological images after PDT differed from those for cancerous tissues. In the case of healthy tissues, areas with damaged testicles due to PDT were found much less frequently and in a small area. Histological images obtained during the tests are shown in Figure 6.

Extremely important elements affecting the effectiveness of PDT are the depth of penetration and the efficiency of light delivery. The depth of penetration in living tissues, which are a complex dynamic and turbid medium, depends on many parameters. The wavelength, light intensity, polarization of light and its coherence are not without significance. Also, tissue physiology, in particular pigmentation, fibrosis structure, composition has an impact (17). Therefore, all these parameters must be

Table 3. $T_{2}$ values of the larynx cancer tissues during subsequent stages of PDT.

\begin{tabular}{|l|c|c|c|c|c|c|}
\hline \multicolumn{1}{|c|}{$\mathrm{T}_{2}(\mathrm{~ms})$} & $\mathrm{C} 1$ & $\mathrm{C} 2$ & $\mathrm{C} 3$ & $\mathrm{C} 4$ & $\mathrm{C} 5$ & C6 \\
\hline START & 94.28 & 97.40 & 100.80 & 103.40 & 102.10 & 114.70 \\
\hline Water + RB $+\mathrm{O}_{2}$ & 96.03 & 105.40 & 106.10 & 105.80 & 113.60 & 116.40 \\
\hline After $15 \mathrm{~min} \mathrm{hv}$ & 98.82 & 108.10 & 109.20 & 107.60 & 115.80 & 118.20 \\
\hline After 30 min hv & 98.55 & 108.60 & 109.10 & 106.70 & 116.70 & 116.60 \\
\hline
\end{tabular}

Table 4. $\mathrm{T}_{2}$ values of the larynx health tissues during subsequent stages of PDT.

\begin{tabular}{|l|c|c|c|c|c|}
\hline \multicolumn{1}{|c|}{$\mathrm{T}_{2}(\mathrm{~ms})$} & $\mathrm{H} 1$ & $\mathrm{H} 2$ & $\mathrm{H} 3$ & $\mathrm{H} 4$ & $\mathrm{H} 5$ \\
\hline START & 78.16 & 81.65 & 92.19 & 92.94 & 102.10 \\
\hline Water + RB $+\mathrm{O}_{2}$ & 80.49 & 91.59 & 94.70 & 101.90 & 109.10 \\
\hline After 15 min hv & 81.78 & 100.70 & 96.70 & 102.40 & 118.10 \\
\hline After 30 min hv & 82.25 & 101.70 & 99.32 & 120.20 \\
\hline
\end{tabular}


taken into account in order to allow tissue penetration as deeply as possible (18). Visible light in the most permeable region of the spectrum (red) has an overall penetration depth in the range of 2 to $6 \mathrm{~mm}$, depending on the wavelength and tissue. Numerous studies have shown that the depth of PDT biological action causing necrosis, apoptosis, or vascular collapse occurs at about twice as deep, i.e. 4-12 $\mathrm{mm}$. This means that about $10 \%$ of the incident light is sufficient to cause a photodynamic effect in tissue (19). Most solid tumors arising in epithelial tissue have an optical penetration depth of 3 to $5 \mathrm{~mm}$ for a $600 \mathrm{~nm}$ light wavelength, up to about $10 \mathrm{~mm}$ for an $800 \mathrm{~nm}$ light wavelength (20). Grecco et al. studied the depth of penetration in vivo and in vitro using a femtosecond laser light with a wavelength of 630 $\mathrm{nm}$. The average values of the measured depths of tissue necrosis were $1.0 \pm 0.1 \mathrm{~mm}$ and $2.0 \pm 0.2 \mathrm{~mm}$ for continuous wave and femtosecond illumination, respectively (21).

The efficacy of PDT can be evaluated in ex vivo studies, as demonstrated by Mendoza-Garcia et

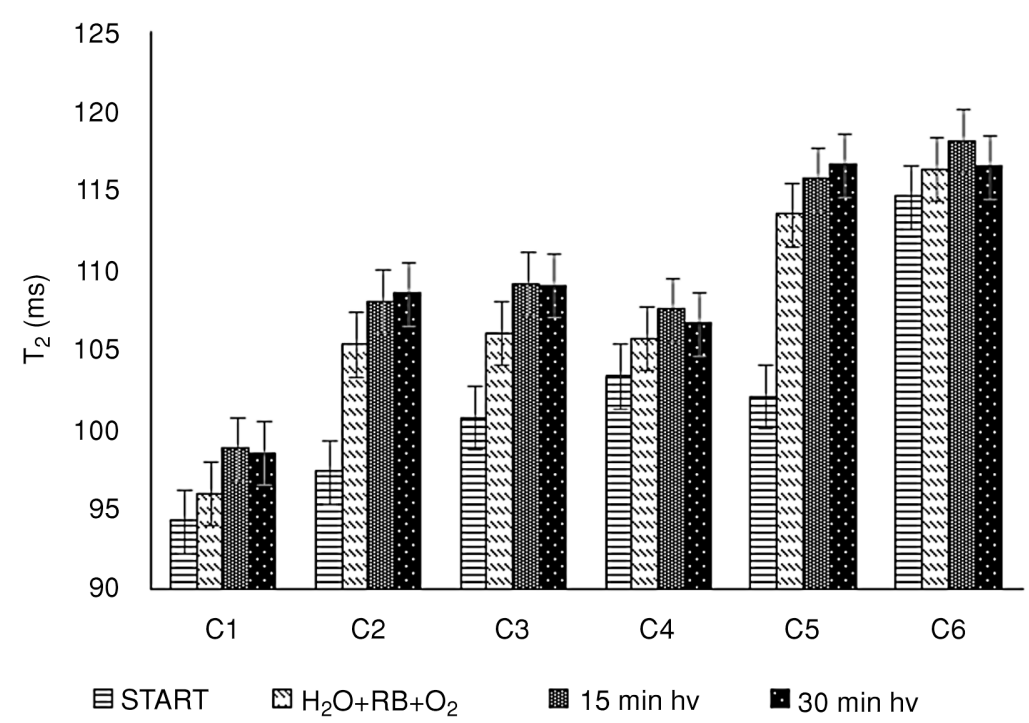

Figure $4 . \mathrm{T}_{2}$ relaxation time results in subsequent study steps for cancer larynx tissues.

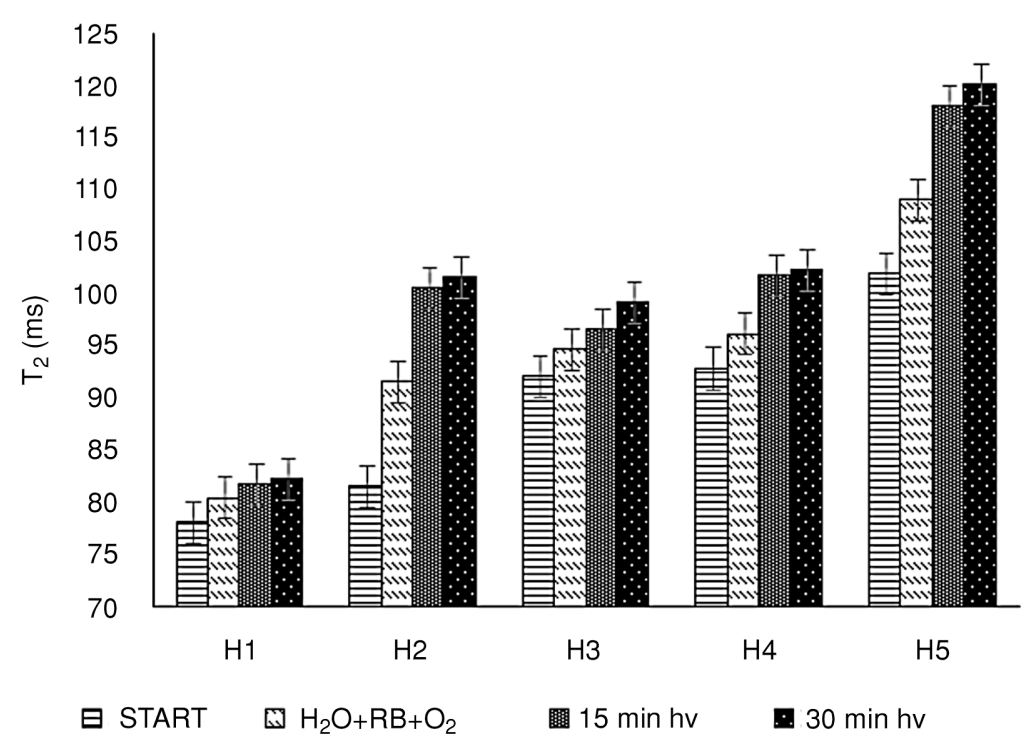

Figure 5. $\mathrm{T}_{2}$ relaxation time results in subsequent study steps for normal larynx tissues. 

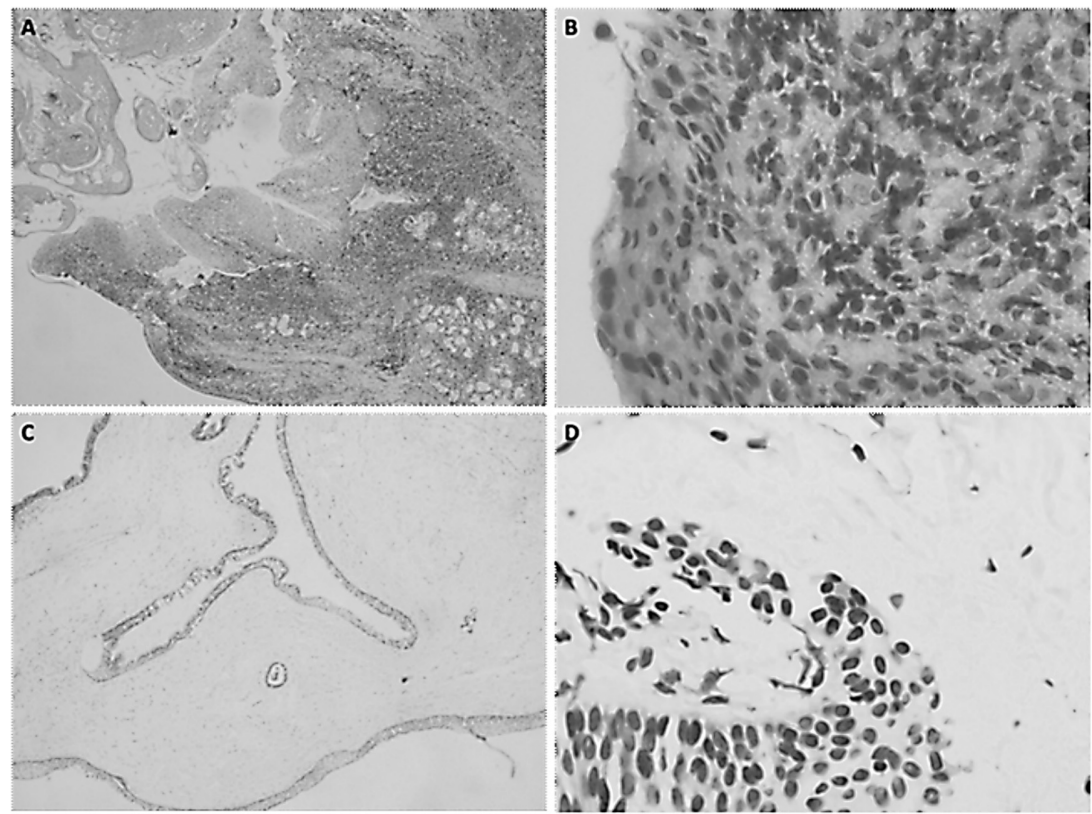

Figure 6. Histology images of larynx cancer (A, B) and health tissue (C, D). A: A general view of the mucosa with keratinized squamous cell carcinoma of the larynx. Abundant chronic inflammatory infiltration is visible. Picture in $4 \times$ magnification. B: Image after two PDT sessions. On the left, a visible epithelium of cancer with a picture of cellular pycnosis. Picture in $63 \mathrm{x}$ magnification. C: A general view of the normal respiratory epithelium. Picture in $4 \mathrm{x}$ magnification. D: Image after two PDT sessions for healthy tissue, a visible epithelium with a picture of cellular pycnosis. Picture in $63 \mathrm{x}$ magnification.

al. in 2015. In the conducted studies, the effect of PDT on excised human skin tissues was evaluated histologically. The results showed an increase in apoptosis and elastic fibers were altered post-PDT (22). Zhang et al. in 2019 evaluated the therapeutic effect of PDT in the treatment of vocal folds. PDT was performed on fresh canine larynges excised postmortem from beagle dogs. Canine larynges were bisected (tissue dimensions were $0.5 \times 1.0 \mathrm{~cm}^{2}$ ), then $125 \mu \mathrm{L}$ of freshly prepared $20 \%$ (weight by weight) 5-ALA hydrochloride (dissolved in normal saline) was used. Topical incubation of 15 min with 5-ALA achieved a penetration depth of over $2 \mathrm{~mm}$. Three hours after applying 5-ALA, PDT was performed using a $635 \mathrm{~nm}$ diode laser. Tissue analysis showed partial epithelial exfoliation after PDT, and the method was assessed as effective (23). Von Beckerath et al. presented the results of the treatment of larynx tumors with PDT. For therapy, a $630 \mathrm{~nm}$ wavelength laser and porphyrin PSs were used. The use of PDT allowed cure larynx cancer in 7 out of 10 patients (24). In summary, there are several limitations to current photodynamic therapy methods that need to be addressed in future research. First, light visible commonly used to initiate photodynamic reaction has a small penetration depth tissues, which limits the clinical application of photodynamic ther- apy to cancer only to the tumor surface. Secondly, singlet oxygen as a toxic radical is responsible for apoptosis and / or necrosis and is generated by the dye photosensitizing at some distance from the tumor cell, and production directly in the cell would be more effective to induce cell death. Third, very often singlet oxygen-generating agents are not targeted target and not localized within the tumor.

We expect that it will be possible to design the photosensitizer nanoparticle that will be used to understand the factors necessary for the clinical application of deep photodynamic therapy tissues in cancerous tumors. More work on the implementation of photodynamic therapy will lead to significant innovation and broadly understood progress in this field of science and will serve as a basis for further clinical treatment.

\section{CONCLUSION}

Photogenerated singlet oxygen is the main agent responsible for cell necrosis during photodynamic cancer therapy. This study showed the potential of photodynamic therapy and MRI to solve the problem of treatment when tumor exists in surgically complex sites, such as when tumors are directly adjacent to vital organs e.g. larynx. 


\section{Acknowledgments}

Dorota Bartusik-Aebisher received Grant New drug delivery systems-MRI study, Grant OPUS-13 issue 2017/25/B/ST4/02481.

\section{Conflict of interest}

The authors declare no conflict of interest.

\section{REFERENCES}

1. Dolmans D.E., Fukumura D., Jain R.K.: Nat. Rev. Cancer 3, 380 (2003).

2. Bacellar I.O., Tsubone T.M., Pavani C., Baptista M.S.: Int. J. Mol. Sci. 16, 20523 (2015).

3. Gluckman J.L., Portugal L.G.: Cancer Treat. Res. Springer, Boston, MA. 74 (1995).

5. Wile A.G., Novotny J., Mason G.R., Passy V., Berns M.W.: Am. J. Clin. Oncol. 7, 39 (1984).

6. Carruth J.A., McKenzie A.L.: Eur. J. Surg. Oncol. 11, 47 (1985).

7. Gluckman J.L.: Aust. NZ. J. Surg. 56, 853 (1986).

8. Yoshida T., Saeki T., Ohashi S., Okudaira T., Lee M., et al.: Nippon Jibiinkoka Gakkai Kaiho 98, 795 (1995).

9. Biel M.A.: Methods Mol. Biol. 635, 281 (2010).

10. Zhang C., Jiang J.Q.: Zhonghua Er Bi Yan Hou Tou Jing Wai Ke za Zhi 53, 306 (2018).
11. Shafirstein G., Rigual N.R., Arshad H., Cooper M.T., Bellnier D.A., et al.: Head Neck. 38, E377 (2016).

12. Zhang C., Gong T., Wang J., Chou A., Jiang J.J.: Laryngoscope 129, E80 (2019).

13. Ożóg Ł., Domka W., Truszkiewicz A., Tarbarkiewicz J., Aebisher D.: Photodiagnosis Photodyn. Ther. 25, 492 (2019).

14. Panek R., Welsh L., Dunlop A., Wong K.H., Riddell A.M., et al.: J. Magn. Reson. Imaging. 44, 72 (2016).

15. Allisy-Roberts P.: Eng. 2. ed. Edinburgh, Saunders, New York 2007.

16. Welsch G.H., Hennig F.F., Krinner S., Tratting S.: Curr. Radiol. Rep. 2, 60 (2014).

17. Ding J., Xing W., Wu D., Chen J., Pan L., et al.: Korean J. Radiol. 16, 827 (2015).

18. Jacques S.L.: Phys. Med. Biol. 58, R37 (2013).

19. Jacques S.L.: J. Biomed. Opt. 15, 05160 (2010).

20. Biomedical Photonics Handbook. Tuan VoDinh, Editor-in-Chief. CEC Press. Boca Raton 2002.

21. Grecco C.V., Moriyama L.T., Cosci A., Pratavieira S.O., Bagnato V.S., Kurachi C.: Lasers Med. Sci. 28, 1177 (2013).

22. Mendoza-Garcia J., Sebastian A., AlonsoRasgado T., Bayat A.: Photodermatol. Photoimmunol. Photomed. 31, 239 (2015).

23. Zhang C., Gong T., Wang J., Chou A., Jiang J.J.: Laryngoscope 129, E80 (2019).

24. von Beckerath M.P., Reizenstein J.A., Berner A.L., Nordqvist K.W., Landström F.J., et al.: Acta Otolaryngol. 134, 852 (2014). 